\title{
No association between three xeroderma pigmentosum group $C$ and one group $G$ gene polymorphisms and risk of cutaneous melanoma
}

Sandra Blankenburg ${ }^{1}$, Inke R König ${ }^{2}$, Rotraut Moessner ${ }^{1}$, Petra Laspe ${ }^{1}$, Kai-Martin Thoms ${ }^{1}$, Ullrich Krueger $^{1}$, Sikandar G Khan ${ }^{3}$, Goetz Westphal ${ }^{4}$, Matthias Volkenandt ${ }^{5}$, Christine Neumann $^{1}$, Andreas Ziegler ${ }^{2}$, Kenneth H Kraemer ${ }^{3}$, Kristian Reich ${ }^{1}$ and Steffen Emmert*,1

${ }^{1}$ Department of Dermatology, Georg-August-University Goettingen, Germany; ${ }^{2}$ Institute of Medical Biometry and Statistics, University Hospital Schleswig-Holstein - Campus Lübeck, Germany; ${ }^{3}$ Basic Research Laboratory, Center for Cancer Research, National Cancer Institute/NIH, Bethesda, MD, USA; ${ }^{4}$ Department of Occupational and Social Medicine, Georg-August-University Goettingen, Germany; ${ }^{5}$ Department of Dermatology, Ludwig-MaximiliansUniversity Munich, Germany

Xeroderma pigmentosum (XP) patients exhibit a 1000-fold increased risk for developing skin cancers including malignant melanoma. We investigated the role of three variant alleles of the DNA repair gene XPC and one variant allele of the XPG gene in a hospital-based case-control study of 294 Caucasian patients from Germany with malignant melanoma and 375 healthy control individuals from the same area matched by sex. The polymorphisms G1580A (XPC exon 8; Arg492His), T1601C (XPC exon 8; Val499Ala), G2166A (XPC exon 10; Arg687Arg), and C3507G (XPG exon 15; Asp1104His) were not in linkage disequilibrium. The allele frequencies (cases: controls) were for $1580 \mathrm{~A} 6.29 \%: 5.63 \%$, for $1601 \mathrm{C} 79.08 \%$ : $78.28 \%$, for $2166 \mathrm{~A} 26.19 \%$ : $28.13 \%$, and for $3507 \mathrm{G} 79.86 \%: 78.61 \%$. We found no association of the homozygous 1580A, 1601C, 2166A, and 3507G genotypes with increased risks of melanoma: OR 1.254 (95\% Cl: 0.486-3.217), OR 1.108 (95\% Cl: 0.629-1.960), OR 0.817 (95\% Cl: $0.490-1.358$ ), and OR 1.168 (95\% Cl: $0.670-2.044)$, respectively. Exploratory analyses of subgroups of melanoma patients compared to all controls indicated no association of these genotypes with increased risks for development of multiple primary melanomas $(n=28)$, a negative family history for melanoma $(n=277)$, melanomas in individuals with a low number of nevi $(n=273)$, melanomas in individuals older than 55 years $(n=142)$, and melanomas thicker than $1 \mathrm{~mm}(n=126)$.

European Journal of Human Genetics (2005) 13, 253-255. doi:10.1038/sj.ejhg.5201296

Published online 20 October 2004

Keywords: DNA repair; xeroderma pigmentosum; XPC; XPG (ERCC5); cutaneous melanoma

Introduction

Defective DNA repair may lead to increased risk of skin cancer since patients with the rare recessive disorder

*Correspondence: Priv-Doz Dr S Emmert, Department of Dermatology, Georg-August-University Goettingen, Von-Siebold-Strasse 3, 37075 Goettingen, Germany. Tel: + 49551 396410; Fax: + 49551 392414; E-mail: semmert@gwdg.de

Received 22 June 2004; revised 18 August 2004; accepted 19 August 2004 xeroderma pigmentosum (XP) have a $>1000$-fold increase in sunlight-induced skin cancers including cutaneous melanoma. ${ }^{1}$ The defects in XP patients fall into seven nucleotide excision repair (NER) complementation groups: XPA to XPG and a separate group XP variant (XPV) with a defect in DNA polymerase $\eta$. XP complementation group $\mathrm{C}$ (XPC) is the most prevalent form among North Americans and Europeans. The XPG (ERCC5) gene product has been reported to be involved not only in NER but also in the 
Table 1 Analysis of XPC and XPG genotype frequencies, ORs, and 95\% Cls for melanoma and allele frequencies

\begin{tabular}{|c|c|c|c|c|c|c|c|c|c|}
\hline Marker & Genotype & Cases (\%) & Controls (\%) & $O R$ & $95 \% \mathrm{Cl}$ & Two-sided $P^{a}$ & Allele & Cases (\%) & Controls (\%) \\
\hline XPC Ex8 G1580A & $\begin{array}{l}\text { GG } \\
\text { GA } \\
\text { AA }\end{array}$ & $\begin{array}{r}259(88.14) \\
33(11.19) \\
2(0.68)\end{array}$ & $\begin{array}{c}333(89.28) \\
38(10.19) \\
2(0.54)\end{array}$ & $\begin{array}{l}1.12 \\
1.25\end{array}$ & $\begin{array}{l}0.70-1.80 \\
0.49-3.22\end{array}$ & 0.65 & $\begin{array}{l}G \\
A\end{array}$ & $\begin{array}{c}551(93.71) \\
37(6.29)\end{array}$ & $\begin{array}{c}704(94.37) \\
42(5.63)\end{array}$ \\
\hline XPC Ex8 T1601C & $\begin{array}{l}\text { TT } \\
\text { TC } \\
\text { CC }\end{array}$ & $\begin{array}{c}14(4.76) \\
95(32.31) \\
185(62.93)\end{array}$ & $\begin{array}{c}8(2.14) \\
146(39.14) \\
219(58.71)\end{array}$ & $\begin{array}{l}1.05 \\
1.11\end{array}$ & $\begin{array}{l}0.79-1.40 \\
0.63-1.96\end{array}$ & 0.73 & $\begin{array}{l}\mathrm{T} \\
\mathrm{C}\end{array}$ & $\begin{array}{l}123(20.92) \\
465(79.08)\end{array}$ & $\begin{array}{l}162(21.72) \\
584(78.28)\end{array}$ \\
\hline XPC Ex10 G2166A & $\begin{array}{l}\text { GG } \\
\text { GA } \\
\text { AA }\end{array}$ & $\begin{array}{c}158(53.74) \\
118(40.14) \\
18(6.12)\end{array}$ & $\begin{array}{c}192(51.20) \\
155(41.33) \\
28(7.47)\end{array}$ & $\begin{array}{l}0.90 \\
0.82\end{array}$ & $\begin{array}{l}0.70-1.17 \\
0.49-1.36\end{array}$ & 0.45 & $\begin{array}{l}\mathrm{G} \\
\mathrm{A}\end{array}$ & $\begin{array}{l}434(73.81) \\
154(26.19)\end{array}$ & $\begin{array}{l}539(71.87) \\
211(28.13)\end{array}$ \\
\hline XPG Ex15 C3507G & $\begin{array}{l}\text { CC } \\
\text { CG } \\
\text { GG }\end{array}$ & $\begin{array}{c}9(3.07) \\
100(34.13) \\
184(62.80)\end{array}$ & $\begin{array}{c}18(4.81) \\
124(33.16) \\
232(62.03)\end{array}$ & $\begin{array}{l}1.08 \\
1.17\end{array}$ & $\begin{array}{l}0.82-1.43 \\
0.67-2.04\end{array}$ & 0.58 & $\begin{array}{l}\mathrm{C} \\
\mathrm{G}\end{array}$ & $\begin{array}{l}118(20.14) \\
468(79.86)\end{array}$ & $\begin{array}{l}160(21.39) \\
588(78.61)\end{array}$ \\
\hline
\end{tabular}

${ }^{a}$ Genotype frequencies were compared using the Cochrane-Armitage trend test.

repair of oxidative DNA damage. ${ }^{1}$ We hypothesize that variations in DNA repair due to inherited polymorphisms of DNA repair genes might be associated with cancer susceptibility in the general population. Wei et $a l^{2}$ recently demonstrated that reduced DNA repair capacity is an independent risk factor for cutaneous melanoma. Variants of the XPD gene were demonstrated to influence the risk for cutaneous melanoma. ${ }^{3}$ Vodicka et $a l^{4}$ found variations in different lymphocytic DNA repair functions in association with the XPG C3507G polymorphism.

\section{Materials and methods Study subjects}

The patients were recruited from the melanoma clinics at the Departments of Dermatology in Munich and Goettingen. Healthy unrelated control individuals were recruited from the blood donor registries and from local health care personnel. The following parameters were registered for the patients and the controls: sex, age, number of nevi (on both forearms, diameter $>2 \mathrm{~mm}$ ), hair color, eye color, skin type, family history of melanoma, primary tumor thickness, and multiple primary melanomas. The studies were approved by the local ethics committees and informed consent was obtained from all patients and controls.

\section{Genotyping}

The XPC codon 492 and 499 genotypes were determined by cycle sequencing (ABI Prism 310, Darmstadt, Germany) using s80neu 5'-AGC CTC TGA TCC CTC TGA TGA T-3' and S81neu $5^{\prime}$-TCT TTT TTC TGC CTT CTC ACC ATC G-3'. The PCR programme was initiated $3 \mathrm{~min}$ at $95^{\circ} \mathrm{C}$ followed by 35 cycles at $95^{\circ} \mathrm{C}$ for $30 \mathrm{~s}, 63^{\circ} \mathrm{C}$ for $30 \mathrm{~s}, 72^{\circ} \mathrm{C}$ for $45 \mathrm{~s}$ and a final elongation step at $72^{\circ} \mathrm{C}$ for $5 \mathrm{~min}$. The XPC codon 687 genotypes were determined employing a
PCR-restriction-fragment-length-polymorphism (RFLP) assay using S82 s 5'-GAC TGA GTT ACC TTT GTG TCC-3' and S83as 5'-TAC TTC TCC AAG CCT CAC C-3'. The PCR programme was initiated $3 \mathrm{~min}$ at $95^{\circ} \mathrm{C}$ followed by 35 cycles at $95^{\circ} \mathrm{C}$ for $45 \mathrm{~s}, 61^{\circ} \mathrm{C}$ for $45 \mathrm{~s}, 72^{\circ} \mathrm{C}$ for $60 \mathrm{~s}$ and a final elongation step at $72^{\circ} \mathrm{C}$ for $5 \mathrm{~min}$. BmeI cuts in the presence of ' $\mathrm{G}$ ' and divides the $110 \mathrm{bp}$ PCR product into two 65 and $45 \mathrm{bp}$ fragments. The XPG codon 1104 genotypes were determined likewise using 3330-3349 FWD 5'-TTT GAG CTA CTT GAT AAG GC-3' and 3624-3607 REV 5'-CAC CTC CAT TCT TCA CGG-3'. The PCR programme was initiated $3 \mathrm{~min}$ at $95^{\circ} \mathrm{C}$ followed by 35 cycles at $95^{\circ} \mathrm{C}$ for $30 \mathrm{~s}, 55^{\circ} \mathrm{C}$ for $45 \mathrm{~s}, 72^{\circ} \mathrm{C}$ for $60 \mathrm{~s}$ and a final elongation step at $72^{\circ} \mathrm{C}$ for 5 min. MboII cuts in the presence of ' $\mathrm{G}$ ' and divides a $136 \mathrm{bp}$ fragment into two 107 and $29 \mathrm{bp}$ fragments. For control purposes, results were evaluated by SB and PL independently and PCR products were initially sequenced. We ensured that in every RFLP experiment at least one sample showed a restriction enzyme digestion, serving as a positive control.

\section{Statistical analysis}

Observed and expected genotype frequencies were compared by a Monte-Carlo goodness-of-fit test. Odds ratios and exact 95\% confidence intervals were calculated. Genotype frequencies were investigated using the Cochrane-Armitage trend test.

\section{Results}

This analysis included 294 unrelated Caucasian patients from Germany with histopathologically confirmed cutaneous melanoma and 375 healthy cancer-free control individuals from the same area. Applying logistic regression analysis frequencies of the phenotypic melanoma risk factors number of nevi and skin type as well as age were 
significantly different in the melanoma group compared to the control group confirming that these variables are independent risk factors for the development of cutaneous melanoma and are involved in the etiology of melanoma in this study population (all $P<0.0001$, respectively).

The four polymorphisms were not in linkage disequilibrium. No significant deviation of the observed genotype distributions from the expected genotype distributions as predicted by the Hardy-Weinberg theory were detected. We found no association of the homozygous genotypes with increased risks of melanoma (Table 1). The same results were obtained while adjusting for the possible risk factors age, gender, skin type and eye and hair color (data not shown). Exploratory analyses of subgroups of melanoma patients compared to all controls indicated no association of these genotypes with increased risks for the development of multiple primary melanomas $(n=28)$, a negative family history for melanoma $(n=277)$, melanomas in individuals with less than 50 nevi $(n=273)$, melanomas in individuals older than 55 years $(n=142)$, and melanomas thicker than $1 \mathrm{~mm}(n=126)$.

\section{Discussion}

To our knowledge, this is the first case-control study of XPC and XPG polymorphisms in relation to melanoma. The allele frequencies for the XPC G1580A and G2166A polymorphisms were previously unknown. Two of the four polymorphisms may not alter DNA repair: the G2166A base change in XPC exon 10 does not lead to an aminoacid change and Gozukara et $a l^{5}$ reported that both the XPC 1601T and 1601C alleles had similar functional activities using a host cell reactivation-based complementation assay. However, they may be linked to other functionally relevant genetic variations. For example, both alleles of an XPC exon 15 polymorphism (A2920C; Lys939Gln) showed similar DNA repair activities in the complementation assay but further studies revealed that it is associated with the risk for developing bladder cancer. ${ }^{6}$ Another Poly (AT) insertion polymorphism within XPC intron 9 is normally spliced out during XPC mRNA processing but was found to be associated with the development of squamous cell cancer of the head and neck. ${ }^{7}$ Subsequently, it was found that both polymorphisms are in linkage disequilibrium to yet a third XPC splice site polymorphism that exhibits functional relevance. ${ }^{8}$ The XPC exon 8 (G1580A, Arg492His) polymorphism has not been evaluated for its effect on DNA repair. The allele frequencies for the XPC T1601C and XPG C3507G polymorphisms found in the present European population match our previously reported frequencies found in 84 and 91 anonymous donors from the US. ${ }^{5,9}$ In two distinct Scandinavian populations from Sweden and Finland, similar allele frequencies for the XPG C3507G polymorphism and an association with the occurrence of bladder and breast cancer were reported. ${ }^{6,10}$ Interestingly, in a Korean study of 310 lung cancer patients and 311 healthy controls the XPG 3507G allele was found at a frequency between 0.55 and 0.5 rather than 0.8 and 0.79 and was associated with a decreased risk of lung cancer. ${ }^{11}$ This may indicate that the XPG codon 1104 polymorphism varies between ethnic groups. Further studies are necessary to clarify the role of DNA repair gene polymorphisms in melanoma development.

\section{Acknowledgements}

SE was supported by a grant from the Deutsche Forschungsgemeinschaft (EM 63/3-1).

\section{References}

1 Bootsma D, Kraemer KH, Cleaver JE, Hoeijmakers JH: Nucleotide excision repair syndromes: xeroderma pigmentosum, Cockayne syndrome, and trichothiodystrophy; in Vogelstein B, Kinzler KW (eds): The genetic basis of human cancer. New York: McGraw-Hill, 2002; pp 211-237.

2 Wei Q, Lee JE, Gershenwald JE et al: Repair of UV light-induced DNA damage and risk of cutaneous malignant melanoma. $J$ Natl Cancer Inst 2003; 95: 308-315.

3 Tomescu D, Kavanagh G, Ha T, Campbell H, Melton DW: Nucleotide excision repair gene XPD polymorphisms and genetic predisposition to melanoma. Carcinogenesis 2001; 22: 403-408.

4 Vodicka P, Kumar R, Stetina R et al: Genetic polymorphisms in DNA repair genes and possible links with DNA repair rates, chromosomal aberrations and single-strand breaks in DNA. Carcinogenesis 2004; 25: 757-763.

5 Gozukara EM, Khan SG, Metin A et al: A stop codon in xeroderma pigmentosum group $\mathrm{C}$ families in Turkey and Italy: molecular genetic evidence for a common ancestor. J Invest Dermatol 2001; 117: $197-204$.

6 Sanyal S, Festa F, Sakano S et al: Polymorphisms in DNA repair and metabolic genes in bladder cancer. Carcinogenesis 2004; 25: 729-734.

7 Shen H, Sturgis EM, Khan SG et al: An intronic Poly (AT) polymorphism of the DNA repair gene XPC and risk of squamous cell carcinoma of the head and neck: a case-control study. Cancer Res 2001; 61: 3321-3325.

8 Khan SG, Muniz-Medina V, Shahlavi T et al: The human XPC DNA repair gene: arrangement, splice site information content and influence of a single nucleotide polymorphism in a splice acceptor site on alternative splicing and function. Nucleic Acids Res 2002; 30: 3624-3631.

9 Emmert S, Schneider TD, Khan SG, Kraemer KH: The human XPG gene: gene architecture, alternative splicing and single nucleotide polymorphisms. Nucleic Acids Res 2001; 29: 1443-1452.

10 Kumar R, Hoglund L, Zhao C, Forsti A, Snellman E, Hemminki K: Single nucleotide polymorphisms in the XPG gene: determination of role in DNA repair and breast cancer risk. Int J Cancer 2003; 103: 671-675.

11 Jeon HS, Kim KM, Park SH et al: Relationship between XPG codon 1104 polymorphism and risk of primary lung cancer. Carcinogenesis 2003; 24: 1677-1681. 